\title{
ARE USERS' RATINGS ON TRIPADVISOR SIMILAR TO HOTEL CATEGORIES IN EUROPE?
}

\author{
Eva Martin-Fuentes* \\ Carles Mateu** \\ Cesar Fernandez** \\ University of Lleida
}

\begin{abstract}
European countries do not have the same hotel classification system. Therefore, the criteria and requirements used to assign star ratings to hotels do not concur among the different countries. There have been some criticisms about the way hotel stars are assigned, because the requirements do not necessarily match the quality of service offered. Technical criteria such as infrastructure and room dimensions are taken into account, but users do not perceive them although these have nothing to do with the satisfaction. This study aims to determine whether the hotel category of about 80,000 hotels in 9 different European countries on TripAdvisor is related to customer satisfaction, measured from the point of view of the user ratings on this site. The one-way ANOVA test shows that there are significant differences between the average ratings of the hotel category, except in the classification of 1-star and 2-star hotels from most countries analysed that behave similarly, and 1-star and 3-star hotels from Austria, Greece, Portugal, Spain and UK that are ranked similarly..
\end{abstract}

Keywords: star-rate system; eWOM; User-Generated Content; hotels; TripAdvisor; Big data.

Fecha de recepción: 27 de septiembre de 2017.

Fecha de aceptación: 24 de abril de 2018.

* Department of Business Administration.

*** Department of Computer Science.

University of Lleida. C/ Jaume II, 73.25001 LLEIDA (Spain). E-mail: eva.martin@udl.cat, carlesm@diei. udl.cat,cesar@diei.udl.cat 


\section{¿Se parecen las puntuaciones de los usuarios en TripAdvisor con las categorías hoteleras en Europa?}

\section{RESUMEN}

Los hoteles de Europa no siguen el mismo sistema de clasificación hotelera, por lo que los criterios y los requerimientos usados para asignar las estrellas no coinciden entre países, e incluso ni entre regiones de un mismo país. Hay algunas críticas sobre la forma de asignar las estrellas hoteleras porque los requisitos establecidos no coinciden necesariamente con la calidad del servicio ofrecido. Por eso, este estudio determina si la categoría hotelera de más de 80.000 hoteles en 9 países europeos está relacionada con la satisfacción de los clientes, medida a través de las puntuaciones otorgadas en TripAdvisor. A través de un contraste ANOVA se demuestra que hay diferencias significativas entre las puntuaciones medias de cada categoría hotelera, excepto en las categorías de 1 y 2 estrellas en la mayoría de países analizados que se comportan de forma similar, y entre 1 y 3 estrellas de Austria, Grecia, Portugal, España y Reino Unido que también se comportan de manera parecida.

Palabras clave: clasificación hotelera; boca-oreja digital; contenido generado por los usuarios; hotels; TripAdvisor; Big data.

\section{INTRODUCTION}

Hotel classification systems do not follow the same pattern throughout the world because each country has its own criteria, while the European level attempts to launch a process of harmonisation of different regulations by the Hotrec Association (Hotels, Restaurants and Cafes in Europe) to implement a scoring system that allows unity among criteria for allocation of stars in different countries (Hotrec, 2015).

This process is not an easy task, because even within the same countries, there are different systems, for example, Spain has 17 different classifications, as many as some autonomous governments, which have the power to regulate this ranking. In fact, the Hotrec has been working on the harmonization process since 2004 and only 16 European countries are members of the HotelStars Union (HotelStars Union, 2017).

Hotel classifications have been questioned in some studies, not only because countries do not follow the same criteria, but because the hotel classification systems have lost credibility as a quality standard (Núñez-Serrano, Turrión, and Velázquez, 2014) because some of the criteria are outdated (Torres, Adler, and Behnke, 2014) or because the customer expectations are related to the quality of services more than to the hotel classifications (López Fernández and Serrano Bedia, 2004).

Otherwise, although the star-rating classification systems are different all over the world, it has been proven that there is a relationship between star-rating classification and satisfaction measured from the point of view of scores assigned by users on advice websites such as TripAdvisor and on sales websites such as Booking.com (Martin-Fuentes, 2016).

A study conducted by the World Tourism Organization of the United Nations (UNWTO) considers the idea to merge the official hotel classifications with the online guest reviews 
in order to implement an integrative system (Blomberg-Nygard and Anderson, 2016) that allows consumers to combine the search of information through the online reviews filtered by hotel categories.

Online travel reviews are an important information source for travelers before taking the decision to book a hotel (Cezar and Ögüt, 2016) and TripAdvisor is one of the most visited online travel-related website worldwide, gaining importance daily both in the number of users and reviews about destinations, hotels, restaurants, things to do, and since 2016 about airline companies.

The aim of this research is to confirm whether the hotel star-rated classification system matches the user satisfaction measured from the point of view of the ratings obtained from users on TripAdvisor.

Hotel category and customer ratings of a total of 80,000 hotels in 9 different European countries on TripAdvisor were downloaded automatically. The singularity of this study is that the results were obtained from a large volume of data and that contributes to the scarce literature about hotel classification systems.

A review of the literature from word of mouth and hotel classification systems follows this introduction. Next the methodology used for analysing the data, the results and a discussion will be presented. Finally the main conclusions of this study will be described.

\section{LITERATURE REVIEW}

\subsection{Word of mouth}

The word of mouth (WOM) phenomenon has been studied widely in the marketing field (Arndt, 1967) and it refers to the customers' communications about their experiences (E. W. Anderson, 1998).

WOM through Web 2.0 is known as electronic word of mouth (eWOM) (Hennig-Thurau, Gwinner, Walsh and Gremler, 2004) and is defined as "all informal communications directed at consumers through Internet-based technology related to the usage or characteristics of particular goods and services, or their sellers" (Litvin et al. 2008: 461). The eWOM has also captured the attention of recent research-related tourist services (Guo, Barnes and Jia, 2017; Martin-Fuentes, Mateu and Fernandez, 2018; Raguseo and Vitari, 2017; Xiang, Du, Ma and Fan, 2017).

Both, the traditional WOM and eWOM, have been studied concluding that the use of social media before travelling is widely exteded (Martin-Fuentes, Daries-Ramon and Mariné-Roig, 2015). Online travel reviews have increased exponentially and there is usually a huge number of reviews available for the same product or service (De Ascaniis and Gretzel, 2012).

TripAdvisor is the world's largest travel site with more than 500 million reviews and a community of 415 million average unique monthly visitors (TripAdvisor, 2017).

TripAdvisor is one of the most influential eWOM sources in the hospitality and tourism context (Yen and Tang, 2015) not only does it supply a source of information for travellers, but also its data allows researchers to obtain useful information focusing on User-Generated Content (UGC) through the online travel reviews posted by consumers (Ayeh, Au and Law, 2013; Balagué, Martin-Fuentes and Gómez, 2016; Liu, Pennington-Gray, Donohoe and Omodior, 2015; Melián-González, Bulchand-Gidumal and González López-Valcárcel, 2013) and has been the most frequently studied platform in the last five years (Chen and Law, 2016). 
It can be emphasised that the percentage of consumers who consult TripAdvisor before booking a room in a hotel is increasing (Anderson, 2012) and that the consumers' reviews are more credible if they are published in popular online communities of travellers such as TripAdvisor (Casalo, Flavian, Guinaliu and Ekinci, 2015).

\subsection{Hotel classification systems}

Literature on hotel classification systems is rather scarce, finding some studies concerning the regulations applied by the countries (Arcarons i Simon, Goitia Serra and González Aznar, 2008; Minazzi, 2010; Talias, 2016) and some works about the relationship between quality and hotel classification mechanism (Abrate, Capriello and Fraquelli, 2011; López Fernández and Serrano Bedia, 2004; Núñez-Serrano et al., 2014; Torres et al., 2014).

Hotel star-rating classification systems throughout the world are established from various standards set by national or autonomous governments or by independent organizations. This system is universally recognized, and the most common method for classifying hotels is using from 1 to 5 stars, although the requirements to assign the stars differ, depending on the institution that assigns them.

Other symbols such as diamonds awarded by the American Automobile Association (AAA), crowns assigned by the National Tourist Boards in the United Kingdom (NTBs) or suns (Narangajavana and $\mathrm{Hu}, 2008$ ) are used to classify hotels.

There is no common standard concerning what a hotel from each category should provide; rather, obtaining the stars is based on objective criteria, such as infrastructure, services, amenities and the sizes of the rooms or the common spaces.

The star-rating classification mechanism is the most common customer segmentation pattern in the hotel industry (Dioko, So and Harrill, 2013). The highest hotel categories can be considered as an indicator of high quality (Abrate et al., 2011); it can also be assumed that there is a relationship between the hotel category, the room price and guest satisfaction (Martin-Fuentes, 2016).

Often the hotel category is a method used by consumers to select a hotel (NúñezSerrano et al., 2014). Furthermore, the hotel quality can be inferred from their stars (Fang, Ye, Kucukusta and Law, 2016).

Not all scholarly research confirms the relationship between the star-rating classification system and quality. Callan (1995) concluded that customers did not perceive the grades of any hotel rating system as a strongly important indicator in the selection of a hotel. Additionally, López Fernández and Serrano Bedia (2004) found significant differences among expectations, perceptions and hotel categories. Sometimes there is a lack of correspondence between the hotel ranking and the service offered, based on customer expectations (Minazzi, 2010).

A study of the United Nations World Tourism Organization confirms that consumers and hoteliers support the idea of closer integration of hotel classifications and guest reviews proposing a modification to existing classifications systems which includes guest review data (Blomberg-Nygard and Anderson 2016).

On TripAdvisor, hotel categories are shown by stars in the description. The system used to assign the stars on TripAdvisor is provided by a third party depending on the 
country. The United Kingdom gets the category information from the AA, England from VisitEngland and all other European countries from Expedia or Giata (TripAdvisor, 2014).

Guest satisfaction measured from the point of view of the users' ratings has been studied by multiple authors recently (Kim and Park, 2017; Martin-Fuentes, Fernandez, Mateu and Marine-Roig, 2018; Pacheco, 2017; Tussyadiah and Zach, 2017), and although it is not measured in the traditional way, the association of the UGC with the guest experience is strong (Xiang, Schwartz, Gerdes and Uysal, 2015).

\section{RESEARCH AIM AND METHODOLOGY}

According to the existing literature about hotel classification systems and the effects of the ratings posted on TripAdvisor, the aim of this study is to determine whether the hotel star-rated classification system matches the user satisfaction measured by the ratings obtained from past users' scores on TripAdvisor.

We automatically gathered the data from TripAdvisor, taking into account only "hotels," discarding other options. The process took 13 hours and a total of 82,591 hotels on TripAdvisor were downloaded from 9 European countries classified by TripAdvisor as some of the most popular destinations: Austria, Germany, France, Greece, Italy, Poland, Portugal, Spain and the United Kingdom.

The data were collected on August 2016 using an automatically controlled web browser that simulated user navigation (clicks and selections) for TripAdvisor developed in Python.

Some values were missing from our dataset because some properties had not received any ratings by users. After omitting the missing values the dataset consisted of 78,363 hotels and 15,752,196 reviews on TripAdvisor, as shown in Table 1.

Table 1

SAMPLE DATA BY COUNTRIES

\begin{tabular}{lrrrrrr}
\hline Country & Hotels & $\begin{array}{c}\text { Mean } \\
\text { rating }\end{array}$ & $\begin{array}{c}\text { Standard } \\
\text { deviation } \\
\text { rating }\end{array}$ & \multicolumn{1}{c}{$\begin{array}{c}\text { Total } \\
\text { reviews }\end{array}$} & $\begin{array}{c}\text { Mean } \\
\text { reviews }\end{array}$ & $\begin{array}{c}\text { Standard } \\
\text { deviation } \\
\text { reviews }\end{array}$ \\
\hline Austria & 3,527 & 4.13 & .64 & 371,580 & 105.35 & 208.43 \\
Germany & 9,372 & 3.83 & .67 & $1,020,866$ & 108.93 & 257.02 \\
France & 16,647 & 3.71 & .71 & $2,603,677$ & 156.41 & 249.67 \\
Greece & 6,257 & 4.02 & .71 & 985,009 & 157.43 & 274.05 \\
Italy & 19,642 & 3.99 & .63 & $3,447,834$ & 175.53 & 249.86 \\
Poland & 2,415 & 3.87 & .70 & 210,834 & 87.30 & 213.44 \\
Portugal & 1,902 & 3.92 & .64 & 517,165 & 271.91 & 423.36 \\
Spain & 10,424 & 3.83 & .67 & $3,041,784$ & 291.81 & 504.23 \\
UK & 8,177 & 3.95 & .64 & $3,553,447$ & 434.57 & 540.06 \\
\hline Total & 78,363 & 3.89 & .68 & $15,752,196$ & 201.02 & 352.44 \\
\hline
\end{tabular}

The data collected were transferred to a CSV file, which allows analysis of the information. The statistical calculations were performed using SPSS software, version 20. 
The one-way ANOVA test was performed to determine whether there were any significant differences between the mean score of the five hotel categories. It tested the null hypothesis:

$H_{0}: \mu_{1}=\mu_{2}=\mu_{3}=\mu_{4}=$ being $\mu$ the mean score by hotel category

$H_{A}$ : There are at least two group means that are significantly different from each other.

TripAdvisor ranks hotels with stars from 1 to 5 also assigning hotel categories to the midpoints to match all the general categories from one to five stars. In this study the midpoints of each category were assigned to the previous category, so 1.5-star hotels were assigned together with the 1-star hotels; 2.5 to 2-star hotels and so on. A total of 20,202 hotels with non-defined stars were excluded from this part of the study.

\section{RESULTS}

The best hotels rated on average were those from Austria and Greece and the worst were from France, Germany and Spain, as shown in Table 1.

As seen in Table 2 and in Figure 1, on TripAdvisor 1-star hotels from France were the worst rated on average and those from Greece the best; 2-star hotels from Germany were the worst rated and again Greece had the best rated; 3-star hotels from Portugal were the worst and the best were in Greece; 4-star hotels from Spain were the worst on average and those from Austria were ranked the best; and 5-star hotels from Greece were the worst and the best were in Austria and the United Kingdom.

Table 2

HOTEL RATING BY COUNTRIES AND BY HOTEL CATEGORIES

\begin{tabular}{|c|c|c|c|c|c|c|c|c|c|c|}
\hline \multirow{2}{*}{ Star } & \multicolumn{2}{|c|}{ Austria } & \multicolumn{2}{|c|}{ France } & \multicolumn{2}{|c|}{ Germany } & \multicolumn{2}{|c|}{ Greece } & \multicolumn{2}{|c|}{ Italy } \\
\hline & $\mathrm{N}$ & M & $\mathrm{N}$ & M & $\mathrm{N}$ & M & $\mathrm{N}$ & M & $\mathrm{N}$ & M \\
\hline 1 & 9 & 3.50 & 549 & 2.97 & 120 & 3.48 & 152 & 4.04 & 255 & 3.71 \\
\hline 2 & 77 & 3.87 & 3,559 & 3.55 & 785 & 3.49 & 1,195 & 3.92 & 801 & 3.77 \\
\hline 3 & 1,121 & 3.99 & 5,556 & 3.79 & 4,516 & 3.81 & 1,672 & 4.00 & 7,336 & 3.94 \\
\hline 4 & 1,566 & 4.26 & 1,949 & 4.02 & 2,005 & 4.02 & 1,026 & 4.12 & 4,835 & 4.07 \\
\hline 5 & 87 & 4.51 & 296 & 4.39 & 169 & 4.35 & 387 & 4.34 & 382 & 4.38 \\
\hline \multirow{2}{*}{ Star } & \multicolumn{2}{|c|}{ Poland } & \multicolumn{2}{|c|}{ Portugal } & \multicolumn{2}{|c|}{ Spain } & \multicolumn{2}{|c|}{ UK } & \multicolumn{2}{|c|}{ Total } \\
\hline & $\mathrm{N}$ & $\mathrm{M}$ & $\mathrm{N}$ & $\mathrm{M}$ & $\mathrm{N}$ & $\mathrm{M}$ & $\mathrm{N}$ & $\mathrm{M}$ & $\mathrm{N}$ & $\mathrm{M}$ \\
\hline 1 & 27 & 3.33 & 12 & 3.63 & 521 & 3.67 & 131 & 3.92 & 1,776 & 3.49 \\
\hline 2 & 175 & 3.60 & 161 & 3.62 & 1,562 & 3.68 & 736 & 3.69 & 9,051 & 3.65 \\
\hline 3 & 938 & 3.94 & 593 & 3.75 & 3,292 & 3.78 & 3,573 & 3.91 & 28,597 & 3.87 \\
\hline 4 & 356 & 4.17 & 620 & 4.09 & 2,680 & 4.00 & 1,680 & 4.15 & 16,717 & 4.08 \\
\hline 5 & 61 & 4.39 & 144 & 4.42 & 329 & 4.36 & 159 & 4.51 & 2,014 & 4.39 \\
\hline
\end{tabular}




\section{Figure 1 \\ MEAN SCORE BY COUNTRIES AND BY HOTEL CATEGORIES}

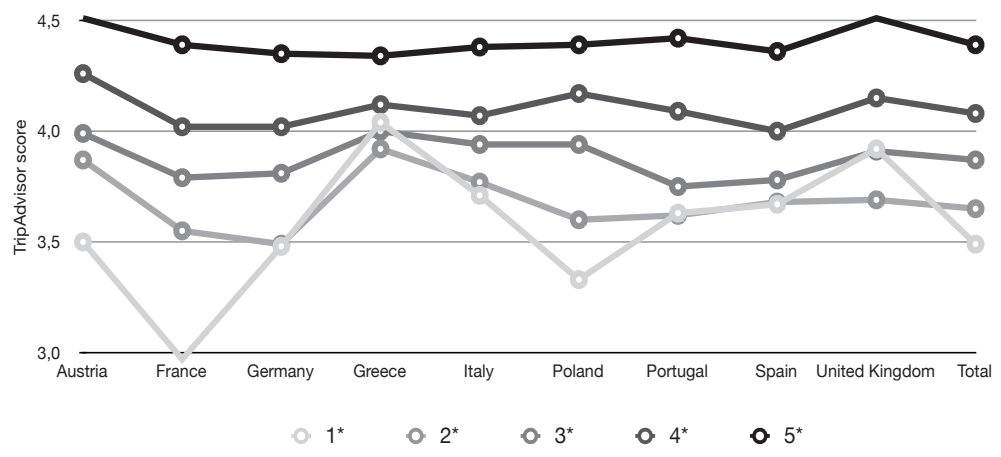

To assess the equality of variances or homoscedasticity, Levene's test was performed and the assumption of homogeneity was not met, because $(\mathrm{F}(4,58150)=559.2, \mathrm{p}<.001)$. Since the assumption of homogeneity of variance was not met for this data, we used the obtained Welch's adjusted $\mathrm{F}$ ratio $(\mathrm{F}(4,7318.5)=1675.5, \mathrm{p}<.001)$. We can conclude that at least two of the five hotel categories differ significantly in their average scores.

Beyond that, post hoc follow-up was performed, since there were unbalanced groups because the number of hotels in each category was different and since the homogeneity of variance assumption was not met, we use the statistical Games-Howell to test the differences between all unique pairwise comparisons. The results concluded that there was a significant effect of mean score awarded by past users on TripAdvisor for all the five hotel categories $(p<.001)$.

By countries, Levene's test showed that the assumption of homogeneity was not met in any country $(\mathrm{p}<.001)$ and in the Welch's adjusted $\mathrm{F}$ ratio $(\mathrm{p}<.001)$. As the data did not meet the homogeneity of variances assumption, we again ran the Games Howell post hoc test to determine which pairs of the five hotel categories differed significantly. The results of the p-value are shown in Table 3.

Table 3

GAMES HOWELL POST HOC TEST (P-VALUE)

\begin{tabular}{|c|c|c|c|c|c|}
\hline Country & $\begin{array}{l}1-2 \text { stars } \\
2-1 \text { stars }\end{array}$ & $\begin{array}{l}\text { 1-3 stars } \\
3-1 \text { stars }\end{array}$ & $\begin{array}{l}\text { 1-4 stars } \\
4-1 \text { stars }\end{array}$ & $\begin{array}{l}2-3 \text { stars } \\
3-2 \text { stars }\end{array}$ & $\begin{array}{c}\text { Other } \\
\text { categories }\end{array}$ \\
\hline Austria & $\mathrm{p}=.484$ & $\mathrm{p}=.213$ & $\mathrm{p}<.05$ & $\mathrm{p}=.646$ & $\mathrm{p}<.05$ \\
\hline France & $\mathrm{p}<.001$ & $\mathrm{p}<.001$ & $\mathrm{p}<.001$ & $\mathrm{p}<.001$ & $\mathrm{p}<.001$ \\
\hline Germany & $\mathrm{p}=1$ & $\mathrm{p}<.001$ & $\mathrm{p}<.001$ & $\mathrm{p}<.001$ & $\mathrm{p}<.001$ \\
\hline Greece & $\mathrm{p}=.307$ & $\mathrm{p}=.960$ & $\mathrm{p}=.640$ & $\mathrm{p}<.05$ & $\mathrm{p}<.001$ \\
\hline Italy & $\mathrm{p}=.793$ & $\mathrm{p}<.001$ & $\mathrm{p}<.001$ & $\mathrm{p}<.001$ & $\mathrm{p}<.001$ \\
\hline Poland & $\mathrm{p}=.285$ & $\mathrm{p}<.001$ & $\mathrm{p}<.001$ & $\mathrm{p}<.001$ & $\mathrm{p}<.001$ \\
\hline Portugal & $\mathrm{p}=1$ & $\mathrm{p}=.931$ & $\mathrm{p}=.069$ & $\mathrm{p}=.092$ & $\mathrm{p}<.05$ \\
\hline Spain & $\mathrm{p}=.999$ & $\mathrm{p}<.05$ & $\mathrm{p}<.001$ & $\mathrm{p}<.001$ & $\mathrm{p}<.001$ \\
\hline UK & $\mathrm{p}<.001$ & $\mathrm{p}=.999$ & $\mathrm{p}<.001$ & $\mathrm{p}<.001$ & $\mathrm{p}<.001$ \\
\hline
\end{tabular}


The results revealed that there were significant differences among most of the categories, except in hotels of 1 and 2 stars from seven countries and except in hotels of 1 and 3 stars from four countries.

1-star and 4-star hotels were not significantly different in Greece and Portugal, as well as 2-star and 3-star hotels in Austria and Portugal.

\section{DISCUSSION}

The mean differences are statistically significant among all categories except the 1-star with 2-star hotels in Austria, Germany, Greece, Italy, Poland, Portugal and Spain; 1-star with 3-star hotels in Austria, Greece, Portugal and United Kingdom; 1-star with 4-star hotels in Greece and Portugal and 2-star with 3-star hotels in Austria and Portugal, which did not show any significantly different mean scores on TripAdvisor.

In most of the countries analysed, there was no mean difference of TripAdvisor scores between 1-star and 2-star hotels. The exception were hotels from France and from the United Kingdom, but as can be observed in Table 2, in the United Kingdom 1-star ratings are better rated by users than those of 2-star hotels.

The 1-star hotels are the ones that have the most different mean score on TripAdvisor. Users rate 1-star hotels differently according to the country, and in some countries this is not the worst score on average as can be seen in Figure 1 but these results should be analysed carefully because, specially in Austria, Poland, and Portugal the percentage of 1 -star hotels of the sample is very low.

Only 1-star and 2-star hotels in seven European countries analysed and 1-star and 3-star hotels in four countries analysed show similarities in the average score of users, a fact that indicates customers do not perceive significant differences in the qualities of these hotels categories. As confirmed by Minazzi (2010), some European countries such as France and Italy have created two main groups: one for the lower categories (1,2 and 3-star hotels), and another for higher categories (4 and 5-star hotels), which is a good proposal looking at our findings that hotels of the lower categories show similarities in the average score of users.

It could be due to the value for money, as confirmed by Martin-Fuentes (2016) there is a relationship between price and hotel category, so the ratings posted by past users could be affected by perceived value received.

Table 2 shows that, in general, the higher a hotel category is, the higher score it obtained as awarded by past users on TripAdvisor. From this we can conclude that the hotel system classification is a good source of information despite studies indicating that the star classification system criteria are obsolete (Torres et al., 2014) or that there is a necessity to implement policies to unify the hotel classification system in Europe to let the hotel stars "shine again" (Arcarons i Simon et al., 2008). Therefore it is demonstrated in this study that the overall quality of hotels can be inferred from their stars in line with Fang et al., (2016).

In general, the consumer confirms the validity of the hotel classification system determined by different rules and regulations in Europe. With each additional star category, a hotel presents a higher level of user satisfaction, as measured by the assessment given on TripAdvisor. So the results show that the hotel classification system adequately fulfills its function as customer ratings increase with each additional star. 
Previous studies indicate that customers of hotels in higher categories are more demanding and quality is associated with service according to customer expectations, rather than the category of the establishment (López Fernández and Serrano Bedia, 2004). However, our study supports the idea that there is a relationship between the hotel category and user satisfaction.

The United Kingdom shows a different pattern in the mean score in 1-star and 2-stars. Because 1-star hotels are better rated than 2-star hotels, it could be linked to the research conducted by Callan (1995) that found that customers of 1-star and 2-star hotels in the United Kingdom use ratings systems less often than those staying in 3-star to 5-star hotels.

This finding could help the industry to closer fit the classification systems with the online reviews in order to include UGC to future classification systems to be consistent with customer needs (Blomberg-Nygard and Anderson 2016).

\section{CONCLUSIONS}

Differences of criteria in the allocation of hotel categories in European countries, even though they differ among regions inside the same country, do not present a problem, as there is a relationship between the category of a hotel and user satisfaction. This is evident from the point of view of the score awarded by past guests on TripAdvisor since higher category hotels have been given better scores by customers.

It can be concluded that as the stars in hotels serve to segment customers (Dioko et al. 2013), the opinions of customers are also a source of segmentation that allows better positioning of each hotel.

Given the importance acquired by $\mathrm{COP}$ and the online travel reviews as a source of information for making reservations at a hotel (Xiang and Gretzel, 2010) and that some research claims there are more flexible regulations for the hotel classification system (Arcarons i Simon et al., 2008), regulations could take into account UGC for the allocation of hotel stars, and, thus, avoid criteria that can become outdated with the passage of time.

From the point of view of hotel management, these findings highlight the importance of a hotel classification system. Seeing that more than 20,000 hotels in Europe do not have stars assigned on TripAdvisor, it is recommended that consumers be aware of the information provided, not only on websites, blogs, ads or social networks controlled by them, but also by the different online distribution channels and other COPs, such as TripAdvisor. As claimed by Denizci Guillet and Law (2010), in some cases the stars differ from reality which can confuse users and damage the reputation of the hotel.

The main singularity of this study is the big data analytics as we analysed most hotels in nine European countries on TripAdvisor, so the results would be impossible to obtain with survey studies.

Finally, as all investigations this is not without limitations. The data obtained allow us to draw conclusions for TripAdvisor only. Although TripAdvisor is very popular and has a large number of reviews, it may be biased in relation to nationalities using the website. Therefore, empirical replications with data obtained from other traveller opinion websites could bring greater insight into the discussion. 


\section{REFERENCES}

ABRATE, G., CAPRIELlO, A. and FRAQUELli, G. (2011): "When quality signals talk: Evidence from the Turin hotel industry". Tourism Management, 32 (4), 912-921. ANDERSON, C.K. (2012): "The Impact of Social Media on Lodging Performance". Cornell Hospitality Report, 12 (15), 4-11.

ANDERSON, E.W. (1998): “Customer Satisfaction and Word of Mouth". Journal of Service Research, 1 (1), 5-17.

ARCARONS I SIMON, R., GOITIA SERRA, V. and GONZÁLEZ AZNAR, N. (2008): "La clasificación hotelera en la Unión Europea: Un mercado poco común". Papers de Turisme, 43-44, 49-67.

ARNDT, J. (1967): "Role of product-related conversations in the diffusion of a new product". Journal of Marketing Research, 291-295.

AYEH, J.K., AU, N. and LAW, R. (2013): “Do We Believe in TripAdvisor?” Examining Credibility Perceptions and Online Travelers' Attitude toward Using User-Generated Content". Journal of Travel Research, 52, 437-452.

BALAGUÉ, C., MARTIN-FUENTES, E. and GÓMEZ, M.J. (2016): "Fiabilidad de las críticas hoteleras autenticadas y no autenticadas: El caso de TripAdvisor y Booking. com." Cuadernos de Turismo, 38, 63-82.

BLOMBERG-NYGARD, A. and ANDERSON, C. K. (2016): "United Nations world tourism organization study on online guest reviews and hotel classification systems: an integrated approach". Service Science, 8 (2), 139-151.

CALLAN, R.J. (1995): "Hotel classification and grading schemes, a paradigm of utilisation and user characteristics". International Journal of Hospitality Management, 14 (3), 271-283.

CASALO, L.V., FLAVIAN, C., GUINALIU, M. and EKINCI, Y. (2015): “Do online hotel rating schemes influence booking behaviors?" International Journal of Hospitality Management, 49, 28-36.

CEZAR, A. and ÖGÜT, H. (2016): "Analyzing conversion rates in online hotel booking". International Journal of Contemporary Hospitality Management, 28 (2), 286-304.

CHEN, Y.-F. and LAW, R. (2016): “A Review of Research on Electronic Word-of-Mouth in Hospitality and Tourism Management". International Journal of Hospitality and Tourism Administration, 17 (4), 347-372.

DE ASCANIIS, S. and GRETZEL, U. (2012): What's in a review title?. In M. Fuchs, F. Ricci, and L. Cantoni (Eds.)Information and Communication Technologies in Tourism, New York, Springer, pp. 460-470.

DENIZCI GUILLET, B . and LAW, R. (2010): “Analyzing hotel star ratings on third $\square$ party distribution websites". International Journal of Contemporary Hospitality Management, 22 (6), 797-813.

DIOKO, L.A.N., SO, S.-I. AMY and HARRILL, R. (2013): "Hotel category switching behavior-Evidence of mobility, stasis or loyalty. International Journal of Hospitality Management, 34, 234-244.

FANG, B., YE, Q., KUCUKUSTA, D. and LAW, R. (2016): “Analysis of the perceived value of online tourism reviews: Influence of readability and reviewer characteristics". Tourism Management, 52, 498-506. 
GUO, Y., BARNES, S.J. and JIA, Q. (2017): "Mining meaning from online ratings and reviews: Tourist satisfaction analysis using latent dirichlet allocation". Tourism Management, 59, 467-483.

HENNIG-THURAU, T., GWINNER, K.P., WALSH, G. and GREMLER, D.D. (2004): "Electronic word-of-mouth via consumer-opinion platforms: What motivates consumers to articulate themselves on the Internet?". Journal of Interactive Marketing, 18 (1), 38-52.

HOTELSTARS UNION. (2017): Strategic Partnership for Hotel Classification in Europe. Retrieved September 25, 2017, from https://www.hotelstars.eu/fileadmin/Dateien/ PORTAL_HSU/Factsheet_01_17.pdf

HOTREC. (2015): Hotrec. Retrieved from http://www.hotrec.eu/newsroom/press-releases-1714/hotelstars-union-polished-the-criteria-for-its-hotelstars-categories.aspx

KIM, W. G. and PARK, S.A. (2017): "Social media review rating versus traditional customer satisfaction”. International Journal of Contemporary Hospitality Management, 29 (2), 784-802.

LITVIN, S. W., GOLDSMITH, R. E. and PAN, B. (2008): "Electronic word-of-mouth in hospitality and tourism management". Tourism Management, 29 (3), 458-468.

LIU, B., PENNINGTON-GRAY, L., DONOHOE, H. and OMODIOR, O. (2015): "New York City Bed Bug Crisis as Framed by Tourists on Tripadvisor". Tourism Analysis, 20 (2), 243-250.

LÓPEZ FERNÁNDEZ, M.C. and SERRANO BEDIA, A.M. (2004): "Is the hotel classification system a good indicator of hotel quality?" Tourism Management, 25 (6), 771-775.

MARTIN-FUENTES, E. (2016): "Are guests of the same opinion as the hotel star-rate classification system?” Journal of Hospitality and Tourism Management, 29, 126-134.

MARTIN-FUENTES, E., DARIES-RAMON, N. and MARINÉ-ROIG, E. (2015): "Satisfacción y fuentes de información de los estudiantes de movilidad universitarios". Opción, 31 (Especial 2), 712-729.

MARTIN-FUENTES, E., FERNANDEZ, C., MATEU, C. and MARINE-ROIG, E. (2018): "Modelling a grading scheme for peer-to-peer accommodation: Stars for Airbnb". International Journal of Hospitality Management, 69, 75-83.

MARTIN-FUENTES, E., MATEU, C., AND FERNANDEZ, C. (2018): "The more the merrier? Number of reviews versus score on TripAdvisor and Booking.com". International Journal of Hospitality and Tourism Administration, in press.

MELIÁN-GONZÁLEZ, S., BULCHAND-GIDUMAL, J. and GONZÁLEZ LÓPEZ-VALCÁRCEL, B. (2013): “Online customer reviews of hotels: As participation increases, better evaluation is obtained”. Cornell Hospitality Quarterly, 54 (3), 274-283.

MINAZZI, R. (2010): "Hotel classification systems: a comparison of international case studies". Acta Universitatis Danubius. Economica, 6 (4), 64-86.

NARANGAJAVANA, Y. and HU, B. (2008): "The Relationship Between the Hotel Rating System, Service Quality Improvement, and Hotel Performance Changes: A Canonical Analysis of Hotels in Thailand". Journal of Quality Assurance in Hospitality and Tourism, 9 (1), 34-56. 
NÚÑEZ-SERRANO, J.A., TURRIÓN, J. and VELÁZQUEZ, F.J. (2014): “Are stars a good indicator of hotel quality? Assymetric information and regulatory heterogeneity in Spain". Tourism Management, 42, 77-87.

ÖĞÜT, H. and ONUR TAŞ, B.K. (2012): "The influence of internet customer reviews on the online sales and prices in hotel industry". The Service Industries Journal, 32 (2), 197-214.

PACHECO, L. (2017): “Customer Satisfaction in Portuguese Hotels: Evidence for Different Regions and Hotel Segments”. Tourism Analysis, 22 (3), 337-347.

RAGUSEO, E. and VITARI, C. (2017): "The Effect of Brand on the Impact of e-WOM on Hotels' Financial Performance". International Journal of Electronic Commerce, 21 (2), 249-269.

TALIAS, M. (2016): "Voluntary hotel regulation as a political compromise". International Journal of Hospitality Management, 56 (Supplement C), 10-17.

TORRES, E.N., ADLER, H. and BEHNKE, C. (2014): "Stars, diamonds, and other shiny things: The use of expert and consumer feedback in the hotel industry". Journal of Hospitality and Tourism Management, 21, 34-43.

TRIPADVISOR. (2014): TripAdvisor Help Center. Retrieved May 13, 2016, from https:// Www.tripadvisorsupport.com/hc/en-us/articles/200614057

TRIPADVISOR. (2017): TripAdvisor, Media Center. Retrieved September 4, 2017, from https://tripadvisor.mediaroom.com/

TUSSYADIAH, I.P. and ZACH, F. (2017): "Identifying salient attributes of peer-to-peer accommodation experience". Journal of Travel and Tourism Marketing, 34 (5), 636-652.

XIANG, Z., DU, Q., MA, Y. and FAN, W. (2017): “A comparative analysis of major online review platforms: Implications for social media analytics in hospitality and tourism". Tourism Management, 58, 51-65.

XIANG, Z. and GRETZEL, U. (2010): "Role of social media in online travel information search". Tourism Management, 31 (2), 179-188.

XIANG, Z., SCHWARTZ, Z., GERDES, J. H. and UYSAL, M. (2015): "What can big data and text analytics tell us about hotel guest experience and satisfaction?" International Journal of Hospitality Management, 44, 120-130.

YEN, C.-L. (ALAN), and TANG, C.-H. (HUGO): (2015): "Hotel attribute performance, eWOM motivations, and media choice". International Journal of Hospitality Management, 46, 79-88.

\section{ACKNOWLEDGEMENTS}

This work was partially funded by the Spanish Ministry of Economy, Industry and Competitiveness: research project TIN2015-71799-C2-2-P, ENE2015-64117-C5-1-R, and ECO2017-88984-R. 